\author{
Stupnytska T. \\ Ph.D., Associate Professor \\ Department of Accounting and Auditing \\ E-mail: t.stupnitska@gmail.com
}

\author{
Volodina 0. \\ Assistant \\ Department of Foreigh Languages \\ E-mail: completeness7@mail.ru
}

\author{
Vasylieva Yu. \\ Undergraduate \\ Department of Accounting and Auditing \\ Odesa National Academy of Food Technologies \\ Kanatna str., 112, Odesa, Ukraine, 65039 \\ E-mail: juliavasileva30@gmail.com
}

\title{
THE PECULIARITIES OF DEBTS RECEIVABLE ACCOUNTING ACCORDING TO THE NATIONAL AND INTERNATIONAL STANDARDS: A COMPARATIVE ASPECT
}

In Ukraine, since the beginning of formation of market relations and so far, a lot of urgent and important questions, connected with debts receivable accounting, have been existed. Therefore, it stipulates constant considering of normative acts and regulating documents, working out of the new ways of perfection of the organization and methods of calculations with debtors. The question of debts receivable management and accounting is rather an important and complicated element, because the financial condition of an enterprise depends to a great extent on presence and efficient management of this type debts.

The question of debts receivable accounting is regulated by the Ukrainian Law "About Accounting and Financial Reporting in Ukraine", national standards of accounting (SA) and international standards of financial reporting (ISFR), as debts receivable refers to the enterprise assets and influences determination of the real financial condition of the enterprise.

The comparative analysis of the aspects of debts receivable accounting according to the national and international standards of accounting has been conducted in the article. The peculiarities of accounting have been considered and common and distinctive features of debts receivable accounting have been determined both according to SA and to ISFR.

Key words: indebtedness, liabilities, debtors, debts receivable, comparative analysis of the aspects of debts receivable accounting, international standards of accounting, national standards of accounting.

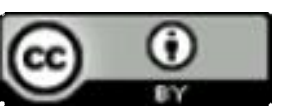

This work is licensed under a Creative Commons Attribution 4.0 International License http://creativecommons.org/licenses/by/4.0/

Statement of the problem and its connection with important scientific and practical tasks. In the modern world practice, management of debts receivable is one of the most important and simultaneously one of the most complicated elements of management of liquid assets. Breaking of the normal cyclic process of its creating and liquidation can not only cause the problems for enterprises (decrease in profitability of assets, loss of their liquidity), but also causes the development of global crisis of non-payments in the economy of any country.

Some scientist's economists focus on the fact that the first signs of bankruptcy are increase of debts receivable, ageing of debtor's accounts, violating of the balance of accounts payable and accounts receivable.

As a result of the reform of accounting, enterprises turn to conducting of the accounting and making of the financial reporting according to the demands of the International Standard of Accounting and International Standards of Financial Reporting, the problem of debts receivable accounting is becoming more acute with every year at the enterprise. Nowadays, the question of debts receivable accounting is regulated by the Law of Ukraine "About Accounting and Financial Reporting in Ukraine", National Standards of Accounting (SA) and International Standards of Financial Reporting (ISFR).

Transition of Ukraine to international standards of accounting, requires for harmonization of standards, which results in necessity of comparison of debts receivable accounting aspects both national and international ones, namely: determination of the term, classification, acknowledgement and evaluation of debts receivable, determination of the reserve value of doubtful debts, reflection in the reporting.

The analysis of the latest publications on the problem. The question of debts receivable accounting according to the national and international standards was paid attention to by a lot, of foreign and domestic scientists, among whom we can name: Butinets F.F., Blank I.A., Batehin S.D., Goretska L.L., Gubachova O.M., Sopka V.V., Skorba O.A., Nashkerska G.V., Melnick S.I. 
and others.

Both in Ukraine and abroad, there is no common concept of debts receivable essence. Interpretation of debts receivable essence by domestic scientists is close to determination of the above - mentioned one in SA 10 "Debts Receivable". According to it, debts receivable are determined as "the sum of debts receivable for a certain date and are divided by the degree of assurance in their liquidation into hopeless and doubtful" [1]. So F.F. Butinets interprets the concept of debts receivable as "sum the of the enterprise debts for a certain date" [9]. A.Z. Popov calls debts receivable as "debt to the advantage of an enterprise" and determines as "this or another part of economic means of an enterprise, which departed from the composition of the given enterprise and is in real disposal of other enterprises, playing the role of capital there" [9].

Kireytsev G.G. thinks that "debts receivable are the demands for payment. Debt requirements are an equivalent of the debt of the person who must carry out the obligations; both the debts and debt requirements are considered from the point of view of their realization term"[12].

But the broadest thought is the thought which the majority of scientists and practical workers keep to, that is determination of debts receivable as debts [6].

The term "debts receivable" in international standards of accounting is significantly different by the content, also we can distinguish accounts receivable and receivables [14].

Accounts receivable are the sums which are received from the customers and reflected in the enterprise books but aren`t confirmed by the bills, drafts or acceptances, that is the total sum that has to be paid by the debtors.

Receivables are the requirements to the third persons for obtaining in the future money, goods and services. Such debts receivable include calculations for debts obtaining from the buyers, who got an installment plan, debts by the bills, debts of the employees, debts of insurance companies by liquidating of property losses [15].
Among foreign authors debts receivable are interpreted as those appeared in the process of realization of goods, works and services. For example, Ye. Brigham determines debts receivable as "the sums, expected from the clients for already sold goods" [8].

In the current national standards of accounting there are arguments concerning interpretation, acknowledgement and evaluation of debts receivable. That's why there is a demand for investigation the essence of debts receivable taking into account the demands of the international practice.

Forming of the aims of the research. The aim of the article is a comparative analysis of the aspects of debts receivable accounting by the national standards and international standards of accounting.

Giving an account of the main results and their substantiation. The standard of accounting 10 "Debts Receivable" clearly determines the main methodological principles of formation of the data in the accounting about debts receivable and their revealing in the financial reporting. In contrast to the national standards of accounting, the international standards don't envisage a separate standard for debts receivable accounting. The principles of such debt accounting can be found in different standards, namely: ISFR 1 "Introduction of the Financial Reporting" - reflection of debts receivable in the financial reporting; ISFR 18 "Income", ISFR 16 "The main means" - recognition of short-term debts receivable without announced interest rate, discounting of the future cash receipts and application of the efficient interest rate during estimation of long-term receivables; ISFR 32 "Financial Instruments: Presentation", ISFR 39 "Financial Instruments: Acknowledgement and Estimation" , ISFR 9 " Financial Instruments" - acknowledgement and debts receivable accounting as a financial instrument and stopping acknowledging it as an asset; ISFR 7 "Financial Instruments: Statement of the Information" - demands for revealing the information about debts receivable in the reporting.

A comparative analysis of the aspects of debts receivable accounting by the national and international standards is given in table 1.

Table 1

Comparison of the aspects of debts receivable accounting by international and national standards *

\begin{tabular}{|l|l|l|}
\hline \multicolumn{1}{|c|}{ Operation } & \multicolumn{1}{|c|}{ SA } & \multicolumn{1}{|c|}{ ISA(ISFR) } \\
\hline Determination & $\begin{array}{l}\text { Debts receivable is the sum of deb- } \\
\text { tors' debts to the enterprise for a } \\
\text { certain date. }\end{array}$ & $\begin{array}{l}\text { According to ISA 32 debts receiva- } \\
\text { ble are determined as a financial as- } \\
\text { set. There is no determination of } \\
\text { debts receivable. }\end{array}$ \\
\hline Classification & $\begin{array}{l}\text { Classification of debts receivables } \\
\text { for production, goods, works, ser- } \\
\text { vices is carried out by grouping of } \\
\text { debts receivable by the terms of its } \\
\text { non-payment: } \\
\text { - current debts receivable } \\
\text { - long-term debts receivable. }\end{array}$ & $\begin{array}{l}\text { According to ISA 1, debts receivable } \\
\text { are divided into: } \\
\text { non-current (long-term) and } \\
\text { current. } \\
\text { According to ISA 39 debts receiva- } \\
\text { ble are divided into: } \\
\text { - initiated by on enterprise; } \\
\text { - not-initiated. }\end{array}$ \\
\hline
\end{tabular}


Continue of table 1

\begin{tabular}{|c|c|c|}
\hline $\begin{array}{l}\text { Acknowledgement of debts } \\
\text { receivable }\end{array}$ & $\begin{array}{l}\text { Debts receivable are acknowledged } \\
\text { as an asset if there is a probability of } \\
\text { an enterprise getting future econom- } \\
\text { ic profits and its sum can be for cer- } \\
\text { tain determined (issue } 5 \text { of SA 10). }\end{array}$ & $\begin{array}{l}\text { Acknowledgement of the financial } \\
\text { asset occurs when the organization } \\
\text { becomes a party of the contract } \\
\text { (agreement), when the commitment } \\
\text { on the financial instrument appears. }\end{array}$ \\
\hline Estimation of the debts receivable & $\begin{array}{l}\text { During placing to a balance, debts } \\
\text { receivable for the production, goods, } \\
\text { works, services are valued by a pri- } \\
\text { mary value and for the date of the } \\
\text { balance by genuine merchandising } \\
\text { cost. Genuine merchandising cost is } \\
\text { the primary cost of debts with calcu- } \\
\text { lating the reserve of doubtful debts } \\
\text { SA10. } \\
\text { Estimation of current debts receiva- } \\
\text { ble is carried out for the date of oc- } \\
\text { curring and for the date of conclud- } \\
\text { ing the balance by the primary cost } \\
\text { or genuine cost of realization respec- } \\
\text { tively. }\end{array}$ & $\begin{array}{l}\text { During primary acknowledgement of } \\
\text { the financial asset one should esti- } \\
\text { mate it by its prime cost which is a } \\
\text { fair cost of the compensation given } \\
\text { or received for it. After the primary } \\
\text { acknowledgement, the debts receiv- } \\
\text { able are acknowledged by amortized } \\
\text { prime cost with application of the } \\
\text { method of determination by the ef- } \\
\text { fective interest rate. Amortized } \\
\text { prime cost of the financial asset is } \\
\text { the sum according to which the fi- } \\
\text { nancial asset was estimated during } \\
\text { primary acknowledgement with cal- } \\
\text { culating of any partial writing off } \\
\text { (directly or with application of the } \\
\text { reserves calculation) on diminishing } \\
\text { utility (ISFR } 39 \text { ). The estimation is } \\
\text { carried out for the date of occurring, } \\
\text { date of liquidation and date of mak- } \\
\text { ing balance by the sum of the issued } \\
\text { bill, taking into account a discount } \\
\text { (in case of payment in the period of } \\
\text { a discount presence) and by the sum, } \\
\text { corrected with a discount respective- } \\
\text { ly. }\end{array}$ \\
\hline $\begin{array}{l}\text { Determination of the value of the } \\
\text { doubtful debts reserve }\end{array}$ & $\begin{array}{l}\text { The value of the doubtful debts re- } \\
\text { serve is determined by one of these } \\
\text { methods: } \\
\text { - application of the absolute sum of } \\
\text { doubtful debts; } \\
\text { - application of doubtedness coeffi- } \\
\text { cient. } \\
\text { By the method of application of the } \\
\text { absolute sum of doubtful debts, the } \\
\text { value of the reserve is determined on } \\
\text { the base of the analysis of solvency } \\
\text { of separate debtors. } \\
\text { By the method of application of the } \\
\text { coefficient of doubtedness, the value } \\
\text { of the reserve is calculated by mul- } \\
\text { tiplying of the sum of debts receiva- } \\
\text { ble balance at the beginning of the } \\
\text { period by the doubtedness coeffi- } \\
\text { cient. }\end{array}$ & $\begin{array}{l}\text { The methods of determining the val- } \\
\text { ue of the doubtful debts reserve in } \\
\text { the international standards are not } \\
\text { envisaged. }\end{array}$ \\
\hline Reflection in reporting & By genuine realization value. & $\begin{array}{l}\text { Don't require reflection of debts } \\
\text { receivable in the balance except the } \\
\text { doubtful debts reserve. }\end{array}$ \\
\hline
\end{tabular}

* Compiled by the authors on the basis [1-4]

With the aim of generalizing of the information about the enterprise debts receivable, calculations are used in accounting both in the national and in the international practice.
The list of the calculations, which are used for accounting of the debts receivable in Ukraine and abroad, is given in table 2 . 
The list of the calculations for the debts receivable accounting in domestic and foreign practice *

\begin{tabular}{|l|l|}
\hline \multicolumn{1}{|c|}{ Domestic practice } & \multicolumn{1}{c|}{ Foreign practice } \\
\hline 18 "Long-term debts receivable" & "Long-term financial investments" \\
34 "Short-term bills obtained" & " Calculations before obtaining" \\
36 "Calculations with buyers and customers" & "Advance payments to suppliers and other liquid assets" \\
37 " Calculations with different debtors" & "Lost discounts for payment on time" \\
38 " Doubtful debts reserve" & "Costs for doubtful debts" \\
& "Reserve for the doubtful debts receivable" \\
\hline
\end{tabular}

* Compiled by the authors on the basis [5; 7]

In the foreign practice, in contrast to the domestic one, application of a general calculation plan isn`t envisaged.

In the international practice of debts receivable accounting, the system of giving discounts is widely used. The discounts which are given to the buyers are divided into two groups:

- trade discounts - the size of the proposed discount can be changed depending from the volume of the ordered things;

- cash discounts are given with the aim of stimulating of the advance payment.

For reflecting them in accounting such calculations are used: "Discounts for the payment on time" and "Lost discounts for the payment on time". In Ukraine, such mechanism of discount accounting is not envisaged.

Giving an account of the main results and their substantiation. So, the comparative analysis of the aspects of debts receivable accounting by the national and international standards of accounting, by the results of which the conclusion can be made about presence of both common and different features in debts receivable accounting, has been conducted:

- in the national standards the norms of accounting are clearly regulated and if one doesn't keep to them, it will lead to a certain responsibility.

- in the international standards the general (basic) rules of classification, estimations and acknowledgement of debts receivable have been given, but the concrete definition of these aspects hasn't been reflected and it gives the leaders of the enterprise possibility to be more independent and self-dependent.

In Ukraine nowadays there is a clear norm of conducting the accounting while the foreign companies have the possibility to choose forms of the accounting, methods of reflecting in the financial reporting the information about certain accounting objects as well as during determining of the proper level of the essence, reflect only all proper data of the accounting in the reporting.

As a result of the reform, demand for harmonization of accounting results in necessity to improve home system of debts receivable accounting.

\section{References}

1. Polozhennia (standart) bukhhalterskoho obliku 10 «Debitorska zaborhovanist», zatverdzhene nakazom Ministerstva finansiv Ukrainy №237 vid 08.10.1999 r. : Za stanom na 27 chervnia 2013 roku. (2013). Retrieved from http://zakon2.rada.gov.ua/laws/show/z0725-99

2. Mizhnarodnyi standart bukhhalterskoho obliku 1 «Podannia finansovoi zvitnosti» : Za stanom na 1 sichnia 2012r. (2012). Retrieved from http://zakon5.rada.gov.ua/laws/show/929 013

3. Mizhnarodnyi standart bukhhalterskoho obliku 32 «Finansovi instrumenty: Podannia» : Za stanom na 1 sichnia 2012r. (2012). Retrieved from http://zakon0.rada.gov.ua/laws/show/929_029

4. Mizhnarodnyi standart bukhhalterskoho obliku 39 «Finansovi instrumenty: Vyznannia ta otsinka»: Za stanom na 17 zhovtnia 2013 r. (2013). Retrieved from http://zakon4.rada.gov.ua/laws/show/929 015

5. Instruktsiia pro zastosuvannia Planu rakhunkiv bukhhalterskoho obliku aktyviv, kapitalu, zoboviazan i hospodarskykh operatsii pidpryiemstv i orhanizatsii zatverdzhena nakazom Ministerstva finansiv Ukrainy vid 21.12.99r. № 291 : Za stanom na 12 hrudnia 2017 roku. (2017). Retrieved from http://zakon3.rada.gov.ua/laws/show/z0893-99

6. Blank, I. A. (2002). Upravlenie aktivami. K.: Nika-Tsentr ; Elga.

7. Bondarenko, O. S. (2008). Suchasni pidkhody do obliku debitorskoi zaborhovanosti u vitchyznianii ta zarubizhnii praktytsi. Investytsii: Praktyka Ta Dosvid, (18), 36-39.

8. Brihkhem, Ye. (1997). Osnovy finansovoho menedzhmentu. K.: Molod.

9. Butynets, F. F. (2005). Bukhhalterskyi finansovyi oblik (6th ed.). Zhytomyr: PP «Ruta».

10. Holov, S. F., \& Kostiuchenko, V. M. (2008). Bukhhalterskyi oblik i finansova zvitnist za mizhnarodnymy standartamy (2nd ed.). Kh.: Faktor.

11. Hubachova, O. M., \& Melnyk, C. I. (2012). Oblik u zarubizhnykh krainakh (2nd ed.). K.: Tsentr uchbovoi literatury.

12. Kireitsev, H. H. (2001). Finansovyi menedzhment. Zhytomyr: ZhITI.

13. Luchko, M. R., \& Benko, I. D. (2016). Bukhhalterskyi oblik u zarubizhnykh krainakh. Ternopil: TNEU. 
14. Tsal-Tsalko, Iu. S., Kirieitsev, H. H., \& Lukanov, I. V. (2011). Mizhnarodni standarty bukhhalterskoho obliku ta finansovoi zvitnosti. Zhytomyr: $\mathrm{PP}$ «Ruta».

15. Sharashydze, T. (Trans.). (2009). Mizhnarodni standarty bukhhalterskoho obliku. K.

Received 3 February 2018

Approved 17 February 2018

Available in Internet 31.03.2018

Ступницкая Т.M.

кандидат экономических наук, доцент кафедра учета и аудита

E-mail: t.stupnitska@gmail.com

\section{Володина Е.П.} ассистент

кафедра иностранных языков

E-mail: completeness7@mail.ru

\section{Васильева Ю.В.}

магистрант

кафедра учета и аудита

Одесская национальная академия пищевых технологий

ул. Канатная, 112, г. Одеса, Украина, 65039

E-mail: uliavasileva30@gmail.com

\section{ОСОБЕННОСТИ УЧЕТА ДЕБИТОРСКОЙ ЗАДОЛЖЕННОСТИ ПО НАЦИОНАЛЬНЫМ И МЕЖДУНАРОДНЫМ СТАНДАРТАМ: СРАВНИТЕЛЬНЫЙ АСПЕКТ}

В Украине с начала формирования рыночных отношений и по сей день существует много актуальных и важных вопросов, связанных с учетом дебиторской задолженности. Это соответственно обусловливает постоянный пересмотр нормативных актов и регламентирующих документов, разработка новых путей совершенствования организации и методики расчетов с дебиторами. Вопросы управления и учета дебиторской задолженности является весьма важным и сложным элементом, ведь финансовое состояние предприятия в значительной степени зависит именно от наличия и эффективного управления этим видом задолженности.

Вопросы учета дебиторской задолженности регламентируется Законом Украины «О бухгалтерском учете и финансовой отчетности в Украине», национальными положениями (стандартами) бухгалтерского учета (П(С)БУ) и международным стандартам фринансовой отчетности (МСФО), поскольку дебиторская задолженность относится к составу активов предприятия и влияет на определение реального финансового состояния предприятия. В статье проведен сравнительный анализ аспектов учета дебиторской задолженности по национальным и международным стандартам бухгалтерского учета. Рассмотрены особенности учета и установлено как общие так и отличительные особенности учета дебиторской задолженности по П(С)БУ и МСФО.

Ключевые слова: задолженность, обязательства, дебиторы, дебиторская задолженность, сравнительный анализ аспектов учета дебиторской задолженности, международные стандарты бухгалтерского учета, национальные стандарты бухгалтерского учета.

\section{Ступницька Т.М.}

кандидат економічних наук, доцент кафедра обліку та аудиту

E-mail: t.stupnitska@gmail.com
Володіна О.П. асистент кафедра іноземних мов E-mail: completeness7@mail.ru

\section{Васильєва Ю.В.} магістрант кафедра обліку та аудиту

Одеська національна академія харчових технологій вул. Канатна, 112, м. Одеса, Україна, 65039

E-mail: juliavasileva30@gmail.com

\section{ОСОБЛИВОСТІ ОБЛІКУ ДЕБІТОРСЬКОЇ ЗАБОРГОВАНОСТІ ЗА НАЦІОНАЛЬНИМИ ТА МІЖНАРОДНИМИ СТАНДАРТАМИ: ПОРІВНЯЛЬНИЙ АСПЕКТ}

В Україні від початку формування ринкових відносин і донині існує чимало актуальних та важливих питань, пов'язаних з обліком дебіторської заборгованості. Це відповідно обумовлює постійний 
перегляд нормативних актів і регламентуючих документів, розроблення нових шляхів удосконалення організації та методики розрахунків з дебіторами. Питання управління та обліку дебіторської заборгованості є досить важливим та складним елементом, адже фінансовий стан підприємства значною мірою залежить саме від наявності та ефективного управління цим видом заборгованості.

Питання обліку дебіторської заборгованості регламентується Законом України «Про бухгалтерський облік та фрінансову звітність в Україні» , національними положеннями (стандартами) бухгалтерського обліку (П(С)БО) та міжнародними стандартами фрінансової звітності (МСФ3), оскільки дебіторська заборгованість відноситься до складу активів підприємства і впливає на визначення реального фінансового стану підприємства. У статті проведений порівняльний аналіз аспектів обліку дебіторської заборгованості за національними та міжнародним стандартами бухгалтерського обліку. Розглянуто особливості обліку та встановлено як спільні так і відмінні риси обліку дебіторської заборгованості за П(С)БО та МСБО.

Ключові слова: заборгованість, зобов'язання, дебітори, дебіторська заборгованість, порівняльний аналіз аспектів обліку дебіторської заборгованості, міжнародні стандарти бухгалтерського обліку, національні стандарти бухгалтерського обліку.

\section{Література}

1. Положення (стандарт) бухгалтерського обліку 10 «Дебіторська заборгованість», затверджене наказом Міністерства фінансів України №237 від 08.10.1999 р. : за станом на 27 червня 2013 року [Електронний ресурс] - Режим доступу: http://zakon2.rada.gov.ua/laws/show/z0725-99

2. Міжнародний стандарт бухгалтерського обліку 1 «одання фінансової звітності» : за станом на 1 січня 2012p. [Електронний ресурс] - Режим доступу: http://zakon5.rada.gov.ua/laws/show/929 013

3. Міжнародний стандарт бухгалтерського обліку 32 «Фінансові інструменти: подання» : за станом на 1 січня 2012p. [Електронний ресурс] - Режим доступу: http://zakon0.rada.gov.ua/laws/show/929 029

4. Міжнародний стандарт бухгалтерського обліку 39 «Фінансові інструменти: визнання та оцінка» : за станом на 17 жовтня 2013 р. [Електронний ресурс] - Режим доступу: http://zakon4.rada.gov.ua/laws/show/929 015

5. Інструкція про застосування Плану рахунків бухгалтерського обліку активів, капіталу, зобов'язань і господарських операцій підприємств і організацій затверджена наказом Міністерства фінансів України від 21.12.99p. № 291 : за станом на 12 грудня 2017 року [Електронний ресурс]. - Режим доступу: http://zakon3.rada.gov.ua/laws/show/z0893-99

6. Бланк И. А. Управление активами / И. А. Бланк. - К.: Ника-Центр; Эльга, 2002. - 702 с.

7. Бондаренко О.С. Сучасні підходи до обліку дебіторської заборгованості у вітчизняній та зарубіжній практиці / О. С. Бондаренко // Інвестиції: практика та досвід. - 2008. - № 18. - С. 36 - 39.

8. Брігхем Є. Основи фінансового менеджменту / С. Брігхем ; пер. з анг. - К. : Молодь, 1997. -1000 с.

9. Бутинець Ф. Ф. Бухгалтерський фінансовий облік: [підручник] / Ф. Ф. Бутинець. - [6-те вид., перероб. і доп.]. - Житомир : ПП «Рута», 2005. - 756 с.

10. Голов С. Ф. Бухгалтерський облік і фінансова звітність за міжнародними стандартами / С. Ф. Голов, В. М. Костюченко. - [2-ге вид., перероб. і доп.]. - Х. : Фактор, 2008. - 1008 с.

11. Губачова О.М. Облік у зарубіжних країнах: [підручник] / О.М. Губачова, С.І. Мельник. - [2-е вид., перероб. та доп.]. - К.: Центр учбової літератури, 2012. - 400 с.

12. Кірейцев Г. Г. Фінансовий менеджмент : [навч.-довідн. посібн.] / Г. Г. Кірейцев. - Житомир : ЖITI, 2001. $-432 \mathrm{c}$.

13. Лучко, М. Р. Бухгалтерський облік у зарубіжних країнах: [навч. посіб.] / М. Р.Лучко, І. Д. Бенько. Тернопіль : ТНЕУ, 2016. - 370 с.

14. Міжнародні стандарти бухгалтерського обліку та фінансової звітності : [навч.-довідн. посібн.] / [Ю.

С. Цал-Цалко, Г. Г. Кірєйцев, І. В. Луканьов та ін.]. - Житомир: ПП «Рута», 2011. - 707 с.

15. Міжнародні стандарти бухгалтерського обліку / переклад Т. Шарашидзе. - К.: 2009. - 730 с.

Стаття надійшла 3.02.2018

Стаття прийнята до друку 17.02.2018

Доступно в мережі Internet 31.03.2018 